\title{
The Effect of the COVID-19 Pandemic on Learning Quality and Practices in Higher Education-Using Deep and Surface Approaches
}

\author{
Salah Alhammadi (D)
}

check for updates

Citation: Alhammadi, S. The Effect of the COVID-19 Pandemic on Learning Quality and Practices in Higher Education-Using Deep and Surface Approaches. Educ. Sci. 2021, 11, 462. https://doi.org/10.3390/ educsci11090462

Academic Editor: Han Reichgelt

Received: 6 August 2021

Accepted: 22 August 2021

Published: 25 August 2021

Publisher's Note: MDPI stays neutral with regard to jurisdictional claims in published maps and institutional affiliations.

Copyright: (C) 2021 by the author. Licensee MDPI, Basel, Switzerland. This article is an open access article distributed under the terms and conditions of the Creative Commons Attribution (CC BY) license (https:/ / creativecommons.org/licenses/by/ $4.0 /)$.
Business Studies Department, Arab Open University, 6 St, Al-Ardiya Industrial Area, Farwaniya 130333, Kuwait; salhammadi@aou.edu.kw

\begin{abstract}
This paper explores the student learning experience using technology as an e-learning tool during the COVID-19 pandemic. This article utilized qualitative methods to examine the quality of student learning using deep and surface approaches to understand what influences student engagement with technology. Interviews were conducted with 21 students from various academic majors using deductive content analysis to evaluate their responses. The findings show that technology increased student engagement with class discussion, and students became more informed about lecture material. It is noteworthy that there were some variations in the students' interpretation of the learning experience with technology, indicating a gap in the quality of learning. Notably, there was an improvement in grades compared to the last online session and the face-to-face learning experience prior to the COVID-19 pandemic, and there were fewer missing quizzes and late assignments. These outcomes may be used to enhance teaching strategies and problem solving within teaching and learning to develop a new mode of delivery. In addition, these findings are important for the future of education in a post-pandemic world.
\end{abstract}

Keywords: COVID-19; e-learning; higher education; teaching and learning process; deep and surface approach; Kuwait

\section{Introduction}

The COVID-19 pandemic has sparked global debates since December 2019, when several cases were reported in Wuhan, China [1]. The coronavirus disease outbreak led to the shutdown of countries around the world, which impacted multiple sectors, including the economy, health, and education, which have been affected tremendously. For example, the COVID-19 pandemic has altered the entire education system, especially higher education. This study examines how the quality of higher education was affected, with a specific focus on the Kuwait higher educational system and what could be done to respond to future challenges. Kuwait schools and universities were closed to prevent the spread of COVID-19 on 26 February 2020 [2]. The country then imposed a curfew on 12 March 2020, which altered not just education but all sectors.

Indeed, education, training, and research are powerful platforms that shape future generations. In a desperate act, governments worldwide took the preventive measure to close down educational institutions and curb the spread of COVID-19 [3]. Lockdown was imposed, and universities were forced to adopt purely online teaching. Thousands of universities around the world closed their campuses [4]. In fact, many nations have adjusted to the pandemic's outcomes by reinstating other alternative means of learning such as online learning. Education industries worldwide have shifted their traditional face-to-face teaching to online learning or e-learning as part of a new phase in education. All of the curriculum materials are accessible through portals with the aid of digital technologies [5]. Consequently, the education calendar has been significantly altered, and it is difficult to predict when traditional campuses will be open again. Higher education 
teaching and learning quality has certainly been affected. Parents, teachers, and students have reported that e-learning does not offer the same educational value that was available before the pandemic struck [6]. For example, during student interviews, many revealed the poor quality and inefficiency of education during online learning.

Despite the great opportunities that online teaching provides, e-learning still has some downsides that affect the quality of learning. Some students may suffer from losing the merit of education due to being discouraged or not taking online education seriously [7]. For instance, students emphasized that they were not engaging as much as they used to while attending classes in person. It is possible that when webcams and microphones are switched off, class engagement is reduced, resulting in some students paying less attention and lacking focus. Another downside presented in online learning during the spread of COVID-19 is that many students are starting to feel disconnected from their peers and experience loneliness. This would significantly affect those who normally attend extracurricular activities such as sports, school clubs, and study groups.

Using technology through Moodle, internet café channels were created to discuss the lecture material among different groups of students and to explore deep and surface student learning approaches. Each group session was led by a different student administrator, who was responsible for picking a topic to be addressed from the weekly relevant curriculum. For example, the administrator would choose a question to be posted and discussed at a time agreed by all students. More importantly, the internet café aims to prepare and assist students with their exams and assignments. The administrator must also clarify any specific issues related to the discussed question. In addition, a WhatsApp group was added to each group to obtain an update and access class information. Every student had the opportunity to actively engage in the internet café. Similarly, students could discuss anything concerning the unit, potentially providing space for informal virtual communication among students to enhance their learning outcomes. The internet café was also intended to provide educational benefits via digital technology related directly to the quality of learning in order to enhance student engagement with the unit material and make them active partners in the teaching and learning process.

To achieve the aim of this research, interviews with different groups of students were conducted to understand students' learning experiences and their perception of the quality of their learning. For example, when exploring how and why students engaged with the internet café, the author examined whether it was to pass the test and get a good grade, to learn what the module is intended to teach, or both. Hence, determining the factors that deter students from actively engaging in the internet café could help develop a plan to enhance learning practices.

Therefore, this research is intended to examine challenges students faced while taking online classes. For example, challenges may emerge from online teaching, such as student engagement during online lectures and how technology can underpin the teaching strategies [8].

Furthermore, efforts were made to assess the students' learning experiences in the new online atmosphere. An online café was created to discuss the class material for different academic modules to see how technology influenced student engagement and how it affected student learning. The academic modules were undergraduate modules delivered over 14 weeks, with two hours per week. Each module aims to develop the students understanding and knowledge to help them complete their chosen degree.

The remainder of this paper is arranged as follows: Section 2 is a literature review, providing background information and related research outcomes; Section 3 outlines the methodology; Section 4 provides the findings and analysis and discusses the study outcomes; and Section 5 provides concluding remarks.

\section{Literature Review}

Technology has advanced dramatically in recent years, bringing with it more reliable and faster means of digital communication, and this has fed through to the educational 
environment. Education now relies on technology to perform teaching and learning activities [9]. Universities nowadays have increasingly adopted technology to enhance engagement with learning material. For example, active learning strategies strengthen student engagement, and cognitive development allows students to develop critical thinking [10]. Integrating active learning strategies will enable teachers to assess students' performance and understanding and make any necessary changes to enhance the teaching materials. For example, [11] highlighted the use of active learning techniques where lecture discussion and group work are encouraged over the lecture format.

Online teaching and learning contain different resources, tools, roles, pedagogical approaches, structures, virtual meetings, and types of interaction [12,13]. Alexander (2004) suggested that technology is fundamental to significantly transforming and enriching the educational learning environment [14]. This begs the question of how technology can affect the learning experience and pedagogy from the students' perspective. The authors of [15] mentioned that higher education institutions struggle to meet the demand for nontraditional students, such as those participating through online courses. However, many higher education institutions have turned to hybrid and online courses to reach a wider pool of students and reduce costs.

It is essential to understand the various student learning strategies. As Marton and Saljo (2005) argued, learning approaches are generally divided into two categories: "deep" and "surface" approaches [16]. For example, a student using a surface approach tends to engage minimally with the course material. In surface-level processing, the student memorizes the information without necessarily understanding it and is extrinsically motivated by a deadline [17]. Meanwhile, a student using a deep approach focuses more on understanding the course topics and being able to explain them to another learner and creating a link between different ideas. A student practicing the deep approach is proactive and highly engaged with the topic, and they are intrinsically motivated by their personal interest $[18,19]$. The authors of [18] found the surface approach to often be associated with low-level understanding, leading to poor learning outcomes and superficial knowledge. In contrast, the deep approach is associated with a higher level of understanding, leading to good learning outcomes and a profound understanding of the educational content. From a teaching perspective, students do not intrinsically adopt a deep or surface approach; rather, it depends on their perception of specific learning contexts.

Technology can act as a facilitator or barrier to high-quality learning. Different studies on the impact of technology on the quality of student learning have demonstrated that technology may support high-quality education and a deep learning approach but may also hinder it [20]. In fact, technology is just a tool that students will engage with and use differently, where approaches to learning and technology interact. For example, how students use technology depends on their perceptions of the teaching and learning environment based on their own prior experiences and motivations, and how teachers have set up the learning environment. The authors of [20] explored the dimensions of online hybrid learning relevant to education by examining the primary factors contributing to the success and failure of online learning, including measuring learning outcomes and understanding students' learning experiences using specific learning tools. For instance, students have positive or negative attitudes toward technology acceptance, which influence their readiness to engage with technology. A positive effect of technology may lead to gaining knowledge and valuable learning experiences, which could be related to a deep approach. However, adverse effects may lead to avoidance, which may, in turn, result in less knowledge being gained via technology.

Therefore, in conjunction with the internet café, technology acceptance can help dissolve the barrier between students and modern technology in teaching and learning. Students see online courses differently from traditional classes, and any negative perceptions may lead to adverse learning outcomes, potentially affecting their motivation to learn [21]. To overcome the negative perceptions of technology, a student administrator was appointed to manage and post a selected question for peer discussion. Students were given 
the freedom to generate their own learning environment as administrators, encouraging student ownership and engagement with the unit material [22].

Technology has the potential to enhance student learning and improve learning outcomes, as discussed by [23], who focused on technology as a central element of education. Technology has enabled students to access a broader range of resources and facilities, enhancing their research and expanding their knowledge. Other benefits of technology include a diversity of provision, increased access to higher education, efficient delivery, and, most importantly, personalization of learning. Whether teaching is face to face or online, each learner has different needs and preferences [24].

Salmon (2012) discussed three ways of participating online: The first is through distance learning, where participants and the e-moderator do not meet face to face [12]. The second is a supplement to campus-based learning, whereby students meet face to face and benefit from the VLE. The third is a mixture of the previous two and is called blended learning, and this could include seminars, lectures, and online courses. This study focused on distance learning during the COVID-19 pandemic to explore the students learning experience, since the unit was delivered entirely online. According to Salmon (2012), e-moderating is the key to online teaching and learning. For example, e-moderators should set up exercises and online events that promote critical thinking in the discussion, such as commenting on each other's writing. Salmon (2012) mentioned other benefits of having distance learning courses, such as the low cost involved and their promotion of a sustainable environment, and the potential for student development using the elearning approach.

Salmon (2013) discussed the model of online teaching and learning via online networking by discussing the " 5 -stages framework" and "e-tivities", which provide essential support and development for participants to build expertise in online learning [25]. For example, designing courses using these stages would create an effective group discussion and support individual development. The first stage comprises access and motivation by setting up the system and accessing it. The second stage, online socialization, establishes the online identities to be used for sending and receiving messages, which includes users familiarizing themselves with cultural, social, and learning environments. The third stage involves information exchange, during which the participants can search for information and find supporting learning material. The fourth stage, knowledge construction, involves participants having discussions. The fifth stage is a development that provides links outside the discussion form for further support and provides an opportunity for users to benefit from online networking.

Teaching a module that comprises mostly international students who come from different business backgrounds can be challenging. This is important to consider in order to examine the impact of the use of technology on enhancing international students' learning experience. Nevertheless, the focus in this study is the use of the internet café by all students, as indicated earlier. However, according to [26], international students have a tendency to sit back and not get involved in a class discussion, and this may impact negatively on their learning outcomes. This makes it challenging for the lecturer to encourage students to participate during a lecture or outside activities, especially when the unit is largely composed of international students. Of course, there could be many reasons for this, such as a language barrier or cultural differences. Carroll (2015) highlighted the challenges facing teachers who work with international students and across national boundaries with different cultural settings and educational systems, using different examples from experiences of a wide range of disciplines [27].

According to [28], there is an increased number of international students studying at Western universities. The authors of [29] indicated that the UK is among the top five countries that receive international students. International students not only provide a financial and academic contribution but also bring a rich cultural heritage, values, and norms that enable students to play a vital role in their new community [30]. However, international students face some serious challenges when they travel to study and leave 
their family and friends, including language barriers, cultural differences, tuition fees, and the expectation of success from their loved ones. As [31] identified in his study, international students experience a higher level of stress compared to local students, especially first-year students. International students might feel that they are less qualified to attend, and it is very common that they are misunderstood by academic staff. Biggs (1997) stated that it is important to identify any problems that international students experience and to help overcome them, and to make an effort to understand international students' prior learning and adopt the right strategy to encourage cognitive engagement from all students, as this leads to better learning outcomes [28]. Similarly, [32] found that international students are confronted with serious learning difficulties that can impact their learning experience, such as a lack of confidence in their language skills, which prevents them from playing a proactive role during class discussions. Moreover, the fact that language might be a barrier could reduce students' cognitive engagement during class activities. By identifying some of the problematic issues that might prevent students from being more proactive during class discussions, this might help both the students and their teacher to overcome any issues.

Academic staff face a serious challenge regarding the class participation of international students in different courses $[33,34]$. This matter should be addressed to provide a quality outcome as well as student satisfaction with the delivery of the expected teaching programs. Therefore, it is important to recognize any problems that international students face in learning and become familiar with the context to mitigate these issues and improve the teaching process. This emphasizes the importance of not alienating any segment of the student population. It also highlights the significance of exploring alternative provisions for teaching and learning, such as an internet café. The authors of [34] made reference to how teaching practices can be improved in order to enhance the student learning experience, particularly that of international students.

In this study, the aim was to gain insights into the impact of using technology as a complementary student learning tool for high-quality teaching and learning. This article is intended to develop a long-term way in which to improve teaching and learning strategies, in order to ultimately obtain an effective outcome for all students.

\section{Methodology}

Research design: This study implemented qualitative research using interviews. Several authors indicated that qualitative research affords an understanding of phenomena or a situation that shows and tells the story rather than defining a cause and effect $[35,36]$. Additionally, qualitative research can be a good tool when examining a relationship and exploring reasons why an event is taking place [37]. On the other hand, interviews are most effective using qualitative methods and are designed to collect information concerning attributes, behavior, preferences, opinions, or knowledge [36]. For example, an interview can help the researcher explain and explore the research subject and obtain in-depth information using open-ended questions.

The motivation for this project was to explore student learning experiences by creating an internet café and measuring the variation with respect to the quality of learning and the differences in approaches to learning. E-learning has become a new experience, helping both academics and students reach their aims of achieving their desired learning outcomes. It is important to understand the student learning strategies used to improve engagement and learning quality during online learning.

Therefore, this research adopted the commonly used definition for deep and surface learning approaches offered by [25,38], where a deep learner can explain a topic to another learner. Deep learners are those students who are proactive and highly engaged with the subject, using technology as a distance learning tool during the COVID-19 pandemic.

The internet café was intended to discuss learning module materials. Each session of the internet café was managed by a different student administrator, who was responsible for introducing a topic for the week that was relevant to the curriculum being discussed. 
The administrator selected a question to be addressed at a time agreed by all students. Making a student the administrator has an educational rationale: posting a specific question for discussion in the internet café and leading the discussion forum allow students to think independently and take ownership in seeking answers. In addition, a WhatsApp group was established for each group so they received updates and could effortlessly access class information.

Data Collection: Data were obtained using several interviews. Interviewing has been largely used in different research works as a method of data collection [39]. Interviews enable participants to express their views in an open-ended questionnaire, gain feedback, and obtain an in-depth understanding of their experience [40]. An interview would be a more personal method of research than a survey. For example, an interviewer can work directly with the participants and has the opportunity to review and ask more questions. Therefore, this study aimed to examine the student learning experience and the quality of education provided to them using technology. A total of 21 student administrators were interviewed ( 7 from each group) with respect to their perceptions of the online learning experience.

Three classes from different academic majors were selected (Table 1). An online interview was performed among various undergraduate students using a deductive analysis to code their responses and understand their learning practice.

Table 1. Three groups of students compared in this study.

\begin{tabular}{cccc}
\hline Group & Number of Students & Academic Major & Module \\
\hline Group A & 32 & Economics & Introduction to Economics \\
Group B & 29 & Business & Introduction to Business \\
Group C & 30 & Finance & Commercial Banking \\
\hline
\end{tabular}

All groups had a mix of male and female students between the ages of 19 and 32 years. Additionally, all groups included some international students.

The open-ended questionnaire was carried out in the last session of the semester, which allowed all participants to express their views and provide feedback on their learning experiences related to using the internet café to discuss unit subjects. Interview responses were analyzed using the conceptual framework of $[12,16]$ to identify factors that encouraged student engagement with technology and the internet café, and to ascertain the outcomes of their learning experience.

\section{Findings and Discussion}

\subsection{Learners' Perception of Technology}

According to the students' responses, there was a varying degree of the quality of learning, despite them agreeing that technology enhanced their learning practice. As noted by [23], technology provides several advantages, including online library resources. Students' responses indicated that technology is a good source of knowledge and is a time- and energy-saving tool when searching for information. For example, they reported that technology facilitates communication between learners and teachers, and that using technology enables them to access knowledge from multiple sources to enhance their learning. Other students emphasized that technology enabled them to increase the quality of learning and were concerned about writing and researching correctly. For example, they stated that technology makes teaching and learning more accessible, as it was possible to send an email to ask a question instead of having to go to university to ask. While this is true, it could indicate that these individuals were more concerned with convenience than gaining knowledge and the learning itself. Technology also helped to connect classmates, making the course more efficient without face-to-face meetings. It was also reported that technology is beneficial because of the online tools available, such as Google Scholar, and the ability to borrow books online instead of going to the university library.

Responses varied among student groups who were mostly concerned about ease of access and minimal engagement with the unit as tentative passive learners, perhaps to pass 
the course, as per the surface approach [16]. Nevertheless, there was some indication from the interviews that some students may be more concerned about learning the unit material and how technology would help them develop research skills, indicating a deep approach, as suggested by [19].

There was also variation in students' use of technology regarding the quality of learning. For example, responses from group A indicated that being in a classroom provides an opportunity to interact with fellow students, and that this produces positive outcomes such as teaching among peers and exchanging knowledge. In comparison, online teaching lacks deep student interactions.

\subsection{Motivations and Challenges for Learning Using Technology}

The primary purpose of making a student an administrator is the educational rationale of posting a specific question for discussion in the internet café and leading the discussion forum. This makes the students think independently and participate in searching for an answer. Students provided different responses to the question regarding motivation for using the internet café. The reactions shown in Table 2 address the main aspects of why administrators chose a particular question for their discussion using technology.

Table 2. Students' responses to learning using technology.

\begin{tabular}{|c|c|}
\hline Group & Student Responses \\
\hline Group (A) & $\begin{array}{l}\text { "I have to go through the lecture note to find a question which could } \\
\text { be a good topic to discuss and help us with the final assignment". } \\
\text { This is a good reaction that makes students review what they have } \\
\text { written during the actual lecture. }\end{array}$ \\
\hline Group (B) & $\begin{array}{l}\text { "In the internet café discussion, one of my colleagues had mentioned } \\
\text { a great source of knowledge, an article that discussed this week class } \\
\text { topic. I have read the article and researched it more to learn it better, } \\
\text { which I could use for my final assignment". } \\
\text { This is a reasonable reaction that could give the student an incentive } \\
\text { to discuss the lecture material more toward a deep learning approach. }\end{array}$ \\
\hline
\end{tabular}

"I came from Nigeria, which poverty is very high, and I wanted to contribute in that regard. Therefore, I have chosen this particular question because I want to know how moral economics can help develop my county regarding poverty" [ ... "What I will learn in

Group (C) my assignment would take it back and have a seminar in my country to address that issue of poverty using ethical financial tools".

"I went to a university back home that never used a computer. For example, there is no adequate measure for plagiarism; students just cut and paste their assignments. However, technology has improved my ability to write and research properly".

Group A consists of 32 undergraduate students in the Introduction to Economics module. Group B consist of 29 students in the Introduction to Business. Group C have 30 students in Finance Commercial Banking. All groups have a mix of males and females between the age of 19-32. Additionally, all groups included some international students.

Students used different ways of searching for information to choose a particular question as the administrator, adopting either a deep or surface approach. For example, some students only posted questions to fulfil the requirements and probably obtained the minimum information to satisfy the administrator role, which was convenient for them. Some students wanted to connect being an administrator with the final assignment to fulfil requirements but also to compare the lecture notes with in-depth research related to a problem. These students' focus was on learning, which could suggest that they are oriented towards extrinsic goals, such as passing the final assignment, meeting a deadline, or fulfilling the administrator role, indicating a surface approach as per [16,41].

Meanwhile, students in group B appeared to go beyond the unit's requirements, searching for further information to strengthen their understanding of a topic. They were trying to build connections to learn more about the subject, indicating a deep learning 
approach. This is interesting because there is often a split in the learning environment. For example, if the assignment requires the students to exercise a high level of cognitive activity, it is a good thing, as they are more likely to search for relationships among key elements of the topic. However, if the assignment does not exercise a high level of cognitive activity, then students may not put in as much effort to learn deeply about the topic.

\subsection{Learning Expectations Using Technology}

To some students, the internet café seems to have had an academic advantage associated with retrieving quality information. While several students called it a powerful pedagogical tool, others were more pragmatic, using it to obtain references for their assignments. According to their responses, technology also allows them to see information from different perspectives. The internet café discussion enabled students to illustrate their points and connect at a deeper level with the subject material. Some students described their engagement during the internet café discussions as a source of information regarding the exams and assignment. Therefore, it will be beneficial to look at students' engagement in the teaching and learning environment of the internet café to analyze their learning experiences.

If we compare the advantages of online approaches with traditional face-to-face teaching, the students' responses align with [12], who found that e-moderating is the key to online teaching and learning. For example, group A mentioned that the internet café made them more relaxed and less shy, which may also be linked to language, cultural barriers, or emotional issues.

Some students in group A mentioned that they feel more comfortable discussing lecture material online, and this was especially the case for international students. Other students revealed that they were in their comfort zone and did not feel shy or intimidated, as they do when they are in class. They reported that, in the internet café, everybody can contribute and everybody learns.

Students in group B thought it was easier to contribute during the internet café than during in-class discussions. For example, students discussed the extent of their understanding of the unit's material. Attending the internet café made them read more and complete more work, especially when considering what to discuss to learn more effectively. There were positive remarks describing the internet café as a helpful and pleasant learning environment. Members of group B reported that they were more engaged with the unit during online learning. This seems to facilitate, perhaps as a prerequisite, behavior indicating a deep approach, e.g., searching for more information, discussing material, and making contributions during discussions. Meanwhile, some students were more concerned about being comfortable in their own space.

\subsection{Disengaging in the Teaching and Learning Environment}

Students in all groups reflected certain negative behaviors, such as random discussions, discussing unrelated issues, and time lags in replies. This could detract from the learning aspect of sessions. This drawback could lead to participants becoming disengaged, distracting them from focusing on learning the topic, and may potentially affect learning outcomes. This corroborates the findings of [15], who tested students' positive and negative experiences in hybrid and online courses. Many students in their study believed that their expectations were met in terms of ease of access to information; however, many others expressed negative experiences with regard to online learning outcomes, which hindered them from being proactive and obtaining knowledge.

\subsection{Learning Experiences Using the Internet Café}

It is interesting to see the variation between students' responses and their interpretation of the learning experience with the internet café when they were asked how they would evaluate the overall learning experience of the internet café. Some students thought it was a valuable tool to help them achieve good grades, as it helped them complete assign- 
ments and prepare for exams. Others thought that it was an excellent tool to learn more about the elements of lectures and research in general. This variation indicates a gap in the quality of learning among students. For instance, according to the students' responses, those in group A would complete the minimum amount of work necessary, looking for an easy way to pass the course. However, these students can be encouraged to complete more work or use a high cognitive process by being administrators, which may motivate them to work more and engage with the material effectively. For example, one of the administrators in group A mentioned that "being an administrator has helped to do more work, and I have to go through my lecture note and the internet to find a good question to be discussed" (see Table 3 for more responses). This aspect of the internet café seems to have been particularly important, as the independent work seems to have stimulated students to engage in higher levels of cognitive activity. Furthermore, students become responsible for their own knowledge by being an administrator and need little support beyond what is already available, leading to them developing critical thinking skills and the ability to challenge the given task [12].

Table 3. Student responses related to the learning experience using the internet café.

\begin{tabular}{ll}
\hline Group & \multicolumn{1}{c}{ Student Responses * } \\
\hline Group (A) & $\begin{array}{c}\text { "The internet café helped me with my communication skills, my } \\
\text { assignment, understanding of other people's views, opinion, and ideas". }\end{array}$ \\
\hline "It has been positive in terms of helping me with my research and enabled \\
me to participate actively for the unit". \\
"I can voice my own opinion about different issues, gained more \\
knowledge".
\end{tabular}

Students in group $\mathrm{C}$ were mostly trying to improve their understanding of the topic being studied. They were more concerned about learning the unit material and how technology would help them develop research skills. This indicates that those students were using a deep approach, as explained by [19]. Ultimately, students' reflections varied in terms of the quality of learning and outcomes. For example, the internet café discussion had a positive impact on students in their final exam and assignment results compared to the previous year's students. The benefits of online learning in terms of student development using the e-learning approach are aligned with the students' responses using the internet café, as mentioned by [12]. For instance, students in groups A and B mentioned that the internet café helped them develop their knowledge and communication skills.

In addition, some students commented that the internet café made them more focused on the study topic. Some students' responses indicated that because the lecture is not their responsibility to teach, they could easily become distracted. By contrast, the demands of the internet café session kept students more focused.

Among students' other positive statements about using the internet café, online courses were perceived as positive aspects of the learning experience by students who considered them more convenient. These statements are in line with the findings of [15]. It was reported that the internet café helped students complete their assignments and prepare for final exams and was convenient and accessible. For example, one of the group C students stated that "it is practical to discuss the unit components online, from 
everywhere, such as if students are travelling, we did not miss the discussion session and the information presented".

However, the central negative aspect was the framework of the internet café itself, especially with regard to the delay in responses. While this functionality could be updated in the future, in its present form, it meant some participants became distracted and they lost focus on the topic. In addition, it was reported that irrelevant discussions by some students hindered the focus of the internet café sessions. Some students also experienced a technical issue in the first session, and they did not participate because they did not know how to login or where to go for the session, as they were in the discussion forum instead of the internet café, despite being instructed to go to the internet café session. To avoid this happening in the future, there could be a briefing in class to clearly demonstrate to students how to login to the internet café and to resolve any other technical issues.

Finally, we considered the benefit of online learning in terms of student development using the e-learning approach, where it is incorporated and aligned with the student's responses toward e-learning. For example, students mentioned that the internet café helped them develop their knowledge and communication skills. However, discussing the model by [12] stage by stage to compare it with the internet café, in stage one, the internet café did not meet expectations because some students failed to gain easy access. Nevertheless, all the other stages of Salmon's framework were accomplished by the internet café including online socialization, exchange of information, finding supporting material, and gaining knowledge.

\section{Concluding Remarks}

It is clear that the education system needs reliable and robust technology to enhance teaching and learning approaches. Several interpretations could be extracted to develop and improve teaching strategies based on the students' responses gathered here. These include the diverse range of approaches to learning adopted by students, and the independence gained by enabling students to enhance their engagement with the module's content. For example, active learning techniques increased students' opportunities to become more interactive learners, as appointing a student as an administrator seems a powerful tool in which implementing technology enhances the learning experience. According to students' feedback, being an administrator made them search more to choose an appropriate question for the discussion, which made them read material they otherwise might not have. This is interesting, although it is less related to using technology; however, it seems that the administrator role, in particular, puts the onus on students to do something sophisticated, that is, to understand a matter and find a solution, as students are using cognitive process phases to teach themselves [42].

Nevertheless, students' interview responses provided significant variation in the extent of their learning experience in the internet café. The interviews also provided an insight into the students' learning experiences in terms of enhancing their critical thinking, addressing assignments, and preparing for the final exam. Students attained better results in the exam and produced better assignments than those achieved in previous online taught courses and in the previous year during face-to-face teaching, and this was particularly marked among international students. According to [26], international students tend to be less involved in class discussions, which may negatively impact their learning outcomes. This makes it a challenge for the lecturer to attract students to participate during lectures or outside activities, especially when the unit largely consists of international students. Reasons for this include potential language barriers and cultural differences. The authors of [27] highlighted the challenges that face teachers working with international students, crossing national boundaries with different cultural settings and educational systems. For example, language might be a barrier, potentially reducing cognitive engagement, especially during class activities. This can have some serious learning implications, affecting students' learning outcomes, possibly preventing them from proactively engaging in class discussions [32]. Therefore, the internet café has the 
potential to allow all students, especially international students, to overcome some barriers to using technology in teaching and learning and mitigate issues such as a lack of confidence with language. As students in group $C$ mentioned, the internet café provides a more comfortable setting to discuss the lecture materials.

The students' reflections also identified some limited language fluency issues. For instance, the English language or culture could prevent them from being proactive during class discussions, as they are more comfortable online than in class. This supports the findings of [34] that teaching practice can be improved to enhance student learning experiences by identifying hindrances to student engagement, such as language.

The results of the interviews indicate that there were several different motivations for participating in the internet café. For example, some students started to seek more knowledge, which implies that students could enhance their participation and engagement in all aspects of the discussion. While some students are reluctant to participate during in-class discussions, the internet café allowed them to engage in the discussion or say what they were hesitant to say in class. These observations suggest how the potential of the internet café could be used to develop students' knowledge and improve participation in activities by introducing new learning information.

The internet café described here helped to facilitate deeper cognitive thinking through peer interaction and instructor challenges. It functioned as a flipped classroom pedagogical strategy, which aims to enhance students' engagement and center instruction [43]. For example, some students brought questions to the online class discussion and sought critical comments and feedback, rather than simply being lectured to. However, some issues need to be addressed for future students' engagement. For example, some students engaged minimally to fulfil the requirements, not using the internet café as an essential tool for learning; the authors of [16] call this a surface approach. Some students may think that this is an easy way to pass the course, as some questions posted by students may be in the exam.

Students are essential partners in the education system. Sharing the teaching and learning responsibility with students provides them with skills regarding how to learn a specific subject. For example, making a student a session administrator shows strong partnership, as discussed by [44]. The objective in this case is to make students decision makers by posting their own researched questions and administrating the internet café themselves, enhancing their engagement in class discussion. This approach ensured that students understood the teaching material and learnt based on their own interests. For example, a student may focus more on understanding the course material in order to be able to explain it to another learner, which is significant as it means they engage in a deep approach to learning. This is a great benefit that can help improve teaching and learning practices and develop the course aims and learning outcomes of future teaching units.

Funding: This research received funds from the Arab Open University-Kuwait.

Institutional Review Board Statement: This study was conducted according to the guidelines of the Declaration of Helsinki and approved by the institutional review board.

Informed Consent Statement: Written informed consent was obtained from the participants to publish this paper.

Data Availability Statement: The data are available on request due to privacy and ethical reasons.

Acknowledgments: This research was supported and funded by the research sector, Arab Open University-Kuwait Branch, under decision 21094.

Conflicts of Interest: The author declares no conflict of interest.

\section{References}

1. Al-Awadhi, A.M.; Alsaifi, K.; Al-Awadhi, A.; Alhammadi, S. Death and Contagious Infectious Diseases: Impact of the COVID-19 Virus on Stock Market Returns. J. Behav. Exp. Financ. 2020, 27, 100326. [CrossRef]

2. Alhouti, I. Education During the Pandemic: The Case of Kuwait. J. Prof. Cap. Community 2020, 5, 213-225. [CrossRef] 
3. Ogunode, N.J.; Ndubuisi, A.G.; Terfa, A.C. Impact of the COVID-19 Pandemic on Nigerian Educational Institutions. Electron. Res. J. Eng. Comput. Appl. Sci. 2021, 3, 10-20.

4. Rennert, L.; Kalbaugh, C.A.; Shi, L.; McMahan, C. Modelling the Impact of Presemester Testing on COVID-19 Outbreaks in University Campuses. BMJ Open 2020, 10, e042578. [CrossRef]

5. Khalili, H. Online Interprofessional Education During and Post the COVID-19 Pandemic: A Commentary. J. Interprof. Care 2020, 34, 687-690. [CrossRef] [PubMed]

6. Moghli, M.A.; Shuayb, M. Education under COVID-19 Lockdown: Reflections for Teachers, Students and Parents; Center for Lebanese Studies, American University: Beirut, Lebanon, 2020.

7. Maatuk, A.M.; Elberkawi, E.K.; Aljawarneh, S.; Rashaideh, H.; Alharbi, H. The COVID-19 Pandemic and E-Learning: Challenges and Opportunities from the Perspective of Students and Instructors. J. Comput. High. Educ. 2021, 1-18. [CrossRef]

8. McMurtrie, B. Teaching: How to Engage Students in a Hybrid Classroom. Chron. High. Educ. 2020. Available online: https:/ / www.chronicle.com/newsletter/teaching/2020-07-09 (accessed on 20 August 2021).

9. Engelbrecht, J.; Borba, M.C.; Llinares, S.; Kaiser, G. Will 2020 Be Remembered as the Year in Which Education Was Changed? ZDM 2020, 52, 821-824. [CrossRef] [PubMed]

10. Singh, J. Enhancing Student Success in Health Care Programs: Active Learning in a Hybrid Format. J. Instr. Pedagog. 2017, $18,1-18$.

11. Miller, D.A. Active Learning in Hybrid-Online General Chemistry. In Active Learning in General Chemistry: Whole-Class Solutions; Acs Symposium Series; American Chemical Society: Washington, DC, USA, 2019; Volume 1322, pp. $135-151$.

12. Salmon, G. E-Moderating: The Key to Online Teaching and Learning; Routledge: Cambridge, UK, 2012.

13. Rapanta, C.; Botturi, L.; Goodyear, P.; Guàrdia, L.; Koole, M. Online University Teaching During and after the COVID-19 Crisis: Refocusing Teacher Presence and Learning Activity. Postdigit. Sci. Educ. 2020, 2, 923-945. [CrossRef]

14. Alexander, B. Going Nomadic: Mobile Learning in Higher Education. Educ. Rev. 2004, 39, $28-35$.

15. El Mansour, B.; Mupinga, D.M. Students' Positive and Negative Experiences in Hybrid and Online Classes. Coll. Stud. J. 2007, $41,242-248$.

16. Marton, F.; Saljo, R. Approaches to Learning; Marton, F., Hounsell, D., Entwistle, N., Eds.; The University of Edinburgh: Edinburgh, $\mathrm{UK}, 2005$.

17. McLoone, P.; Oluwadun, A. Approaches to Learning in Higher Education: A Review. Afr. Educ. Res. J. 2014, 2, 110-115.

18. Ramsden, P. Learning to Teach in Higher Education; Routledge: Cambridge, UK, 2003.

19. Prosser, M.; Trigwell, K. Understanding Learning and Teaching: The Experience in Higher Education; McGraw-Hill Education: London, UK, 1999.

20. Saadé, R.G.; He, X.; Kira, D. Exploring Dimensions to Online Learning. Comput. Hum. Behav. 2007, 23, 1721-1739. [CrossRef]

21. Kauffman, H. A Review of Predictive Factors of Student Success in and Satisfaction with Online Learning. Res. Learn. Technol. 2015, 23, 1-13. [CrossRef]

22. Drennon, C. Teaching Geographic Information Systems in a Problem-Based Learning Environment. J. Geogr. High. Educ. 2005, 29, 385-402. [CrossRef]

23. Henderson, M.; Selwyn, N.; Aston, R. What Works and Why? Student Perceptions of 'Useful' digital Technology in University Teaching and Learning. Stud. High. Educ. 2017, 42, 1567-1579. [CrossRef]

24. Berge, Z. E-Moderating: The Key to Teaching and Learning Online; Routledge: New York, NY, USA, 2013.

25. Salmon, G. E-Tivities: The Key to Active Online Learning; Routledge: Cambridge, UK, 2013.

26. Quality Assurance Agency for Higher Education. Chapter B6: Assessment of Students and the Recognition of Prior Learning. In UK Quality Code for Higher Education; Gloucester, UK, 2013. Available online: https:/ / www.kent.ac.uk/teaching/qa/uk-qualitycode/chapter-b6_-assessment-of-students-and-the-recognition-of-prior-learning\%20(1).pdf (accessed on 20 August 2021).

27. Carroll, J. Tools for Teaching in an Educationally Mobile World; Routledge, Taylor \& Francis Group: London, UK; New York, NY, USA, 2015.

28. Biggs, J.B. Teaching for Quality Learning at University: What the Student Does; McGraw-Hill Education: London, UK, 2011.

29. OECD. Oecd Science, Technology and Industry Scoreboard 2013; OECD: Paris, France, 2013.

30. Quaye, S.J.; Harper, S.R. Student Engagement in Higher Education: Theoretical Perspectives and Practical Approaches for Diverse Populations; Routledge: Cambridge, UK, 2014.

31. Burns, R.B. Study and Stress among First Year Overseas Students in an Australian University. High. Educ. Res. Dev. 1991, 10, 61-77. [CrossRef]

32. Sawir, E. Language Difficulties of International Students in Australia: The Effects of Prior Learning Experience. Int. Educ. J. 2005, 6, 567-580.

33. Robertson, M.; Line, M.; Jones, S.; Thomas, S. International Students, Learning Environments and Perceptions: A Case Study Using the Delphi Technique. High. Educ. Res. Dev. 2000, 19, 89-102. [CrossRef]

34. Carroll, J.; Ryan, J. Teaching International Students: Improving Learning for All; Routledge: Cambridge, UK, 2007.

35. Yang, Y.; Cornelius, L.F. Students' Perceptions Towards the Quality of Online Education: A Qualitative Approach. Assoc. Educ. Commun. Technol. 2004, 861-877. Available online: https:/ / eric.ed.gov/?id=ED485012 (accessed on 20 August 2021).

36. Fraenkel, J.R.; Wallen, N.E.; Hyun, H.H. How to Design and Evaluate Research in Education; McGraw-Hill: New York, NY, USA, 2012. 
37. Keis, O.; Grab, C.; Schneider, A.; Öchsner, W. Online or Face-to-Face Instruction? A Qualitative Study on the Electrocardiogram Course at the University of Ulm to Examine Why Students Choose a Particular Format. BMC Med. Educ. 2017, 17, 194. [CrossRef] [PubMed]

38. Biggs, J.; Tang, C. Teaching for Quality Learning Higher Education; The Society for Research into Higher Education: Buckingham, UK, 1999.

39. Yin, R.K. Case Study Research and Applications: Design and Methods, 6th ed.; Sage Publications: Thousand Oaks, CA, USA, 2018.

40. Singh, J.; Matthees, B.; Odetunde, A. Leaning Online Education During COVID-19 Pandemic-Attitudes and Perceptions of Non-Traditional Adult Learners. Qual. Assur. Educ. 2021, ahead-of-print. [CrossRef]

41. Entwistle, N. Teaching for Understanding at University: Deep Approaches and Distinctive Ways of Thinking; Palgrave Macmillan: London, UK, 2009.

42. Biggs, J. What the Student Does: Teaching for Enhanced Learning. High. Educ. Res. Dev. 1999, 18, 57-75. [CrossRef]

43. Gilboy, M.B.; Heinerichs, S.; Pazzaglia, G. Enhancing student engagement using the flipped classroom. J. Nutr. Educ. Behav. 2015, 47, 109-114. [CrossRef] [PubMed]

44. Cook-Sather, A.; Bovill, C.; Felten, P. Engaging Students as Partners in Learning and Teaching: A Guide for Faculty; John Wiley \& Sons: Hoboken, NJ, USA, 2014. 